\title{
Halosmysin A, a Novel 14-Membered Macrodiolide Isolated from the Marine-Algae-Derived Fungus Halosphaeriaceae sp.
}

\author{
Takeshi Yamada *(D), Haruka Kogure, Minami Kataoka, Takashi Kikuchi ${ }^{D}$ and Tomoya Hirano \\ Department of Medicinal Molecular Chemistry, Osaka University of Pharmaceutical Sciences, 4-20-1, Nasahara, \\ Takatsuki, Osaka 569-1094, Japan; e13108@gap.oups.ac.jp (H.K.); e15329@gap.oups.ac.jp (M.K.); \\ t.kikuchi@gly.oups.ac.jp (T.K.); hirano@gly.oups.ac.jp (T.H.) \\ * Correspondence: yamada@gly.oups.ac.jp; Tel./Fax: +81-726-90-1085
}

Received: 2 June 2020; Accepted: 16 June 2020; Published: 18 June 2020

check for updates

\begin{abstract}
Halosmysin A, a new 14-membered macrodiolide with an unprecedented skeleton, was isolated from the fungus Halosphaeriaceae sp. OUPS-135D-4, which, in turn, was obtained from the marine algae Sargassum thunbergii. The chemical structure of the macrodiolide was elucidated using 1D and 2D NMR, as well as high resolution fast atom bombardment mass (HRFABMS) spectral analysis. The absolute stereochemistry was determined via chemical derivatization and comparison with a known compound, $(6 R, 11 R, 12 R, 14 R)$-colletodiol. Additionally, halosmysin A was shown to be very potent against murine P388 leukemia, human HL-60 leukemia, and murine L1210 leukemia cell lines, with $\mathrm{IC}_{50}$ values ranging from $2.2 \pm 3.1$ to $11.7 \pm 2.8 \mu \mathrm{M}$.
\end{abstract}

Keywords: macrodiolide; 14-membered ring; Halosphaeriaceae sp.; Sargassum thunbergii; colletodiol; cytotoxicity

\section{Introduction}

Marine-derived microorganisms are renowned for producing secondary metabolites, which have diverse structures and exhibit unexpected biological properties, making them excellent antitumor chemotherapy agents [1-4]. To date, our group has published numerous papers featuring exploratory research on marine-derived fungal metabolites [5]. As part of this ongoing study, the metabolites of Halosphaeriaceae sp.-a fungus which was separated from the marine algae Sargassum thunbergii-were isolated and characterized. In this study, a new 14-membered macrodiolide was designated as halosmysin A (1), together with the known colletodiol (2) [6] from this fungal strain, (Figure 1). Several related polyketide macrodiolides were isolated from diverse microorganisms, including $\mathbf{2}$, colletoketol (grahamimysins A), colletoll, and colletallol from Colletotrichum capsici [6]; grahamimysins $\mathrm{A}_{1}$ and B from Cytospora sp. [7-9]; 9,10-dihydrocolletodiol from Varicosporina ramulosa [10]; clonostachydiol from Clonostachys cylindrospora [11]; Gliocladium sp. [12] and Xylaria sp. [13,14]; 4-keto-clonostachydiol from Gliocladium sp. [12,15]; cordybislactone from Cordyceps sp. [13]; and acremonol and acremodiol from an unidentified Acremoniu-like anamorphic fungus [16]. These macrodiolides exhibited diverse activities such as antimicrobial, antiosteoporosis, tyrosine kinase inhibition, anthelmintic, and cytotoxicity. Recently, other members of this family, namely acaulones, were isolated from the fungus Acaulium sp.; these acaulones possessed a new skeleton or functional group with the olefin moiety in the macrodiolide [17]. The stereostructures of these compounds were established by applying the several rules of chirality [6,10], X-ray crystallographic analysis [18], and asymmetric total synthesis [19-23]. After revisions were conducted [10,12,13,15], it was confirmed that these macrodiolides consisted of two unsymmetrical subunits, which were grouped into two 
different stereochemistries. The colletodiol-type compound possessed a $6 R, 14 R$ configuration, whereas the clonostachydiol group adopted the opposite orientation (Figure S1). Additionally, these compounds had different skeletal number notations in the 14-membered ring.

Halosmysin A (1), which had a unique skeleton and possessed a thiosilvatin analogue conjugated to the 14-membered macrodiolide, might provide further information about the biological activity of this family, as well as its associated biosynthetic pathways. Herein, the structural determination of 1 was identified using ${ }^{1} \mathrm{H}$ and ${ }^{13} \mathrm{C}$ NMR spectroscopic techniques, while its stereochemistry was defined using NOESY data, information garnered from the $J$ values in the ${ }^{1} \mathrm{H}$ NMR spectrum, and a plausible biosynthesis from $\mathbf{2}$. Since the elucidated stereochemistry of $\mathbf{1}$ was the same as that of $\mathbf{2}$, we adopted the number notations of the 14-membered ring in colletodiol. Additionally, the cytotoxicity of these compounds was tested against murine P388 leukemia, human HL-60 leukemia, and murine L1210 leukemia cell lines.

\section{Results and Discussion}

This fungus was cultured in artificial seawater $(80 \mathrm{~L})$ for four weeks. After incubation, the EtOAc extract of the culture filtrate was purified via cytotoxic assay-directed fractionation using a silica gel column, followed by reverse-phase HPLC, affording halosmysin A (1) (3.2 mg, 0.11\%) and colletodiol (2) $(20.7 \mathrm{mg}, 0.69 \%)$. Since the spectral data, including the specific rotation of 2 , were consistent with published reports $[6,10], 2$ was identified as $(6 R, 11 R, 12 R, 14 R)$-colletodiol. This section may be divided by subheadings. It should provide a concise and precise description of the experimental results, their interpretation, and the experimental conclusions which can be drawn therefrom.

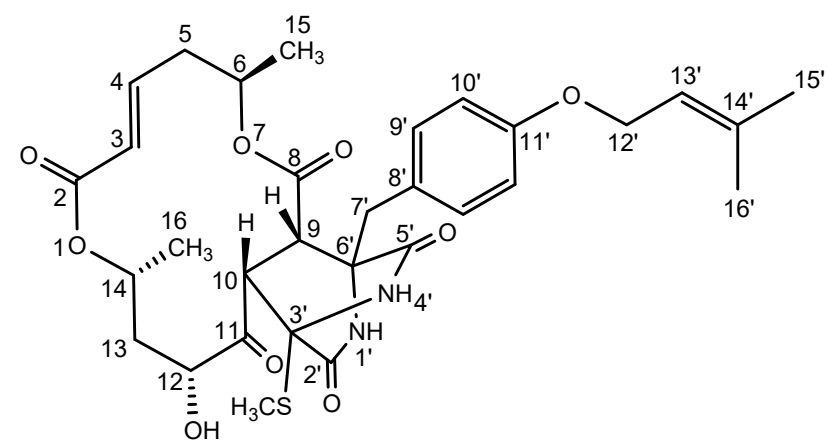

1

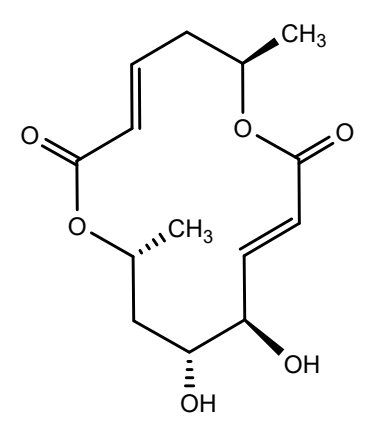

2

Figure 1. Structures of macrodiolides from Halosphaeriaceae sp.

Halosmysin $\mathrm{A}(\mathbf{1})$ was assigned the formula $\mathrm{C}_{31} \mathrm{H}_{38} \mathrm{~N}_{2} \mathrm{O}_{9} \mathrm{~S}$ using HRFABMS $m / z 615.2380[\mathrm{M}+\mathrm{H}]^{+}$ (calcd for $\mathrm{C}_{31} \mathrm{H}_{39} \mathrm{~N}_{2} \mathrm{O}_{9} \mathrm{~S}:$ 615.2376) (Figure S8). Absorption in the IR spectrum at 3393, 2930, 2862, 1752, 1706,1657 , and $1612 \mathrm{~cm}^{-1}$ indicated the presence of hydroxy, amido, and ester moieties, as well as an aromatic ring. Close inspection of the ${ }^{1} \mathrm{H}$ and ${ }^{13} \mathrm{C}$ NMR spectra (Table 1 and Table S1, Figures S2-S7) of 1 using distortionless enhancement by polarization transfer (DEPT) and ${ }^{1} \mathrm{H}-{ }^{13} \mathrm{C}$ correlation spectroscopy (HSQC), revealed the presence of: two secondary methyls (C-15 and C-16); two olefinic methyls (C-15' and C-16'); one thiomethyl group ( $\left.3^{\prime}-\mathrm{SCH}_{3}\right)$; four sp ${ }^{3}$-hybridized methylenes ( $\mathrm{C}-5, \mathrm{C}-13, \mathrm{C}-7^{\prime}$, and $\left.C-12^{\prime}\right)$, of which one was an oxygen-bearing $\mathrm{sp}^{3}$-methine $\left(\mathrm{C}-12^{\prime}\right)$; five $\mathrm{sp}^{3}$-methines $(\mathrm{C}-6, \mathrm{C}-9$, $\mathrm{C}-10, \mathrm{C}-12$, and C-14), of which three were oxygen-bearing sp ${ }^{3}$-methines (C-6, C-12, and C-14); seven $\mathrm{sp}^{2}$-methines $\left(\mathrm{C}-3, \mathrm{C}-4, \mathrm{C}-9^{\prime}, \mathrm{C}-10^{\prime}\right.$, and $\left.\mathrm{C}-13^{\prime}\right)$; two quaternary sp ${ }^{3}$-carbons $\left(\mathrm{C}-3^{\prime}\right.$, and $\left.\mathrm{C}-6^{\prime}\right)$; three quaternary $\mathrm{sp}^{2}$-carbons $\left(\mathrm{C}-8^{\prime}, \mathrm{C}-11^{\prime}\right.$, and $\left.\mathrm{C}-14^{\prime}\right)$; and five carbonyl groups (C-2, C-8, C-11, C-2', and $\left.\mathrm{C}^{-} 5^{\prime}\right)$. In ${ }^{1} \mathrm{H}-{ }^{1} \mathrm{H}$ correlation spectroscopy (COSY), the correlations indicated in bold lines were observed, and five partial structures were elucidated (Figure 2). Analysis of the HMBC spectrum showed the connection of these units with the remaining functional groups. The correlations from $\mathrm{H}-4$ 
to $\mathrm{C}-2$, from $\mathrm{H}-9$ to $\mathrm{C}-8$ and $\mathrm{C}-11$, from $\mathrm{H}-10$ to $\mathrm{C}-8$, and from $\mathrm{H}-13$ to $\mathrm{C}-11$, confirmed the presence of the 14-membered bislactone moiety together with the ${ }^{1} \mathrm{H}$ NMR chemical shifts at H-6 and H-14 ( $\delta$ ppm 5.30 and 5.23, respectively) (Figure 2, Table S1). The large coupling constant $\left(J_{3,4}=16.2 \mathrm{~Hz}\right)$ indicated that the geometrical configuration between C-3 and C-4 was $E$. This bislactone had the same planar structure as colletoketol [6] except for the saturated olefin between C-9 and C-10 (Figure S1). On the other hand, the HMBC correlations-from H-1' (NH) to C-3', from H-4' (NH) to C-2' and C-6', from S-CH to $\mathrm{C}-3^{\prime}$, from $\mathrm{H}-7^{\prime}$ to $\mathrm{C}-5^{\prime}, \mathrm{C}-6^{\prime}, \mathrm{C}-8^{\prime}$, and $\mathrm{C}-9^{\prime}$, from $\mathrm{H}-10^{\prime}$ to $\mathrm{C}-8^{\prime}$ and $\mathrm{C}-11^{\prime}$, from H-12' to C-11' and $\mathrm{C}-14^{\prime}$, and from $\mathrm{H}-15^{\prime}$ and $\mathrm{H}-16^{\prime}$ to $\mathrm{C}-13^{\prime}$ and $\mathrm{C}-14^{\prime}$ - confirmed the presence of the thiosilvatin analogue (Figure 2, Table S1), which had been previously isolated from both Tolypocladium sp. [24] and Fusarium sp. [25,26] as the 3,6-bis(methylthio)-2,5-piperazinedione derivative [27]. Additionally, the correlations from $\mathrm{H}-9$ to $\mathrm{C}-6^{\prime}$, from $\mathrm{H}-10$ to $\mathrm{C}-3^{\prime}$, and from $\mathrm{H}-7^{\prime}$ to $\mathrm{C}-9$, showed that the 14-membered bislactone moiety and the thiosilvatin analogue were bound between C-9 and C-6' and between C-10 and C-3' (Figure 2, Table S1), thereby establishing the planar structure of 1, as shown in Figure 1.

Table 1. NMR spectral data for $\mathbf{1}$ in $\mathrm{CDCl}_{3} \cdot{ }^{\mathbf{b}}$

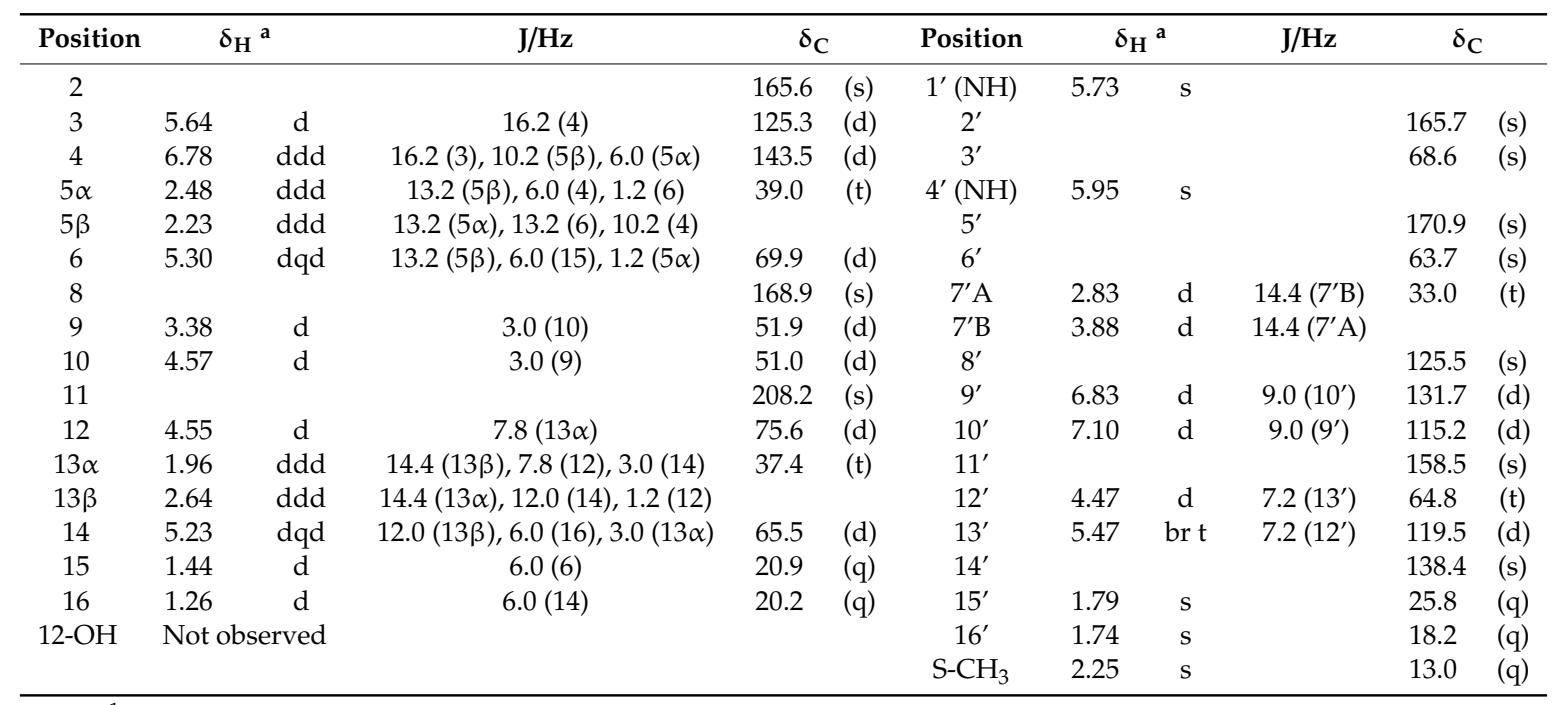

${ }^{\text {a }}{ }^{1} \mathrm{H}$ chemical shift values $\left(\delta \mathrm{ppm}\right.$ from $\left.\mathrm{SiMe}_{4}\right)$ followed by multiplicity and then the coupling constants $(\mathrm{J} / \mathrm{Hz})$;

b $600 \mathrm{MHz}\left({ }^{1} \mathrm{H}\right.$ NMR $), 150 \mathrm{MHz}\left({ }^{13} \mathrm{C}\right.$ NMR).

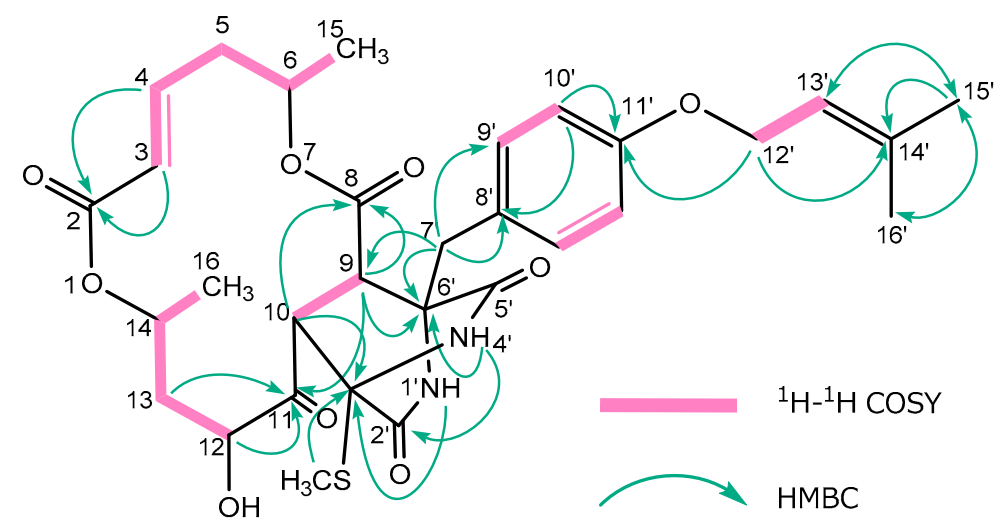

Figure 2. Key ${ }^{1} \mathrm{H}_{-}{ }^{1} \mathrm{H}$ correlation spectroscopy (COSY) and HMBC correlations for $\mathbf{1}$.

For the stereochemistry of $\mathbf{1}$, both the relative configuration and the conformation were investigated via nuclear Overhauser effect spectroscopy (NOESY) experiments and the ${ }^{1} \mathrm{H}$ NMR coupling constant (Table S1 and Figure 3). All of the attempts to induce the crystallization of 1 were unsuccessful. For the 14-membered ring moiety of $\mathbf{1}$, the NOESY correlations between $\mathrm{H}-3$ and $\mathrm{H}-5$ and those between $\mathrm{H}-4$ and $\mathrm{H}-6$, as well as the large coupling constants $\left(J_{5 \alpha, 6}=13.2 \mathrm{~Hz}, J_{5 \beta, 4}=10.2 \mathrm{~Hz}\right)$, confirmed the presence 
of dihedral angles between C-6 and C-5 and between C-5 and C-4 (Figure 3; Newman projection formula A). On the other hand, the NOESY correlations from $\mathrm{H}-16$ to $\mathrm{H}-13$ and $\mathrm{H}-13$, and the large coupling constants $\left(J_{13 \beta, 14}=12.0 \mathrm{~Hz}\right)$, revealed the dihedral angle between $\mathrm{C}-14$ and C-13 (Figure 3; Newman projection formula B). The NOESY correlations between H-3 and H-9, between H-9 and $\mathrm{H}-4^{\prime}(\mathrm{NH})$, and between $\mathrm{H}-10$ and $\mathrm{H}-4^{\prime}(\mathrm{NH})$, showed that both $\mathrm{H}-9$ and $\mathrm{H}-10$ were oriented to the configuration. Additionally, the orientation for H-12 was deduced from the NOESY correlations between $\mathrm{H}-13$ and $\mathrm{H}-10$, and those between $\mathrm{H}-12$ and $3^{\prime}-\mathrm{SCH}_{3}$, together with the small coupling constants $\left(J_{13 \alpha, 12}=7.8 \mathrm{~Hz}, J_{13 \beta, 12}=1.2 \mathrm{~Hz}\right)$. In the thiosilvatin analogue moiety, the NOESY correlations between $\mathrm{H}-4^{\prime}(\mathrm{NH})$ and $\mathrm{H}-9, \mathrm{H}-10$, and $3^{\prime}-\mathrm{SCH}_{3}$, between $\mathrm{H}-12$ and $3^{\prime}-\mathrm{SCH}_{3}$, between $\mathrm{H}-1^{\prime}(\mathrm{NH})$ and H-7' and H-9', and between H-7' and H-9 and H-15, revealed the stereochemistry of C-3' and C-6'. Based on the evidence presented, the relative configuration of $\mathbf{1}$ was established (Figure 1), which was the same as that of the other major co-metabolite from this fungus, colletodiol (2). Based on the information obtained from past synthetic studies about the stereochemistry of this class of 14-membered bislactones, we assumed that $\mathbf{1}$ belonged to the family of colletoketol, colletodiol (2), and grahamimycin $B$ in terms of its absolute configuration, i.e., it possessed $6 R, 12 R, 14 R$ (Figure S1) $[10,12,13,15,19-23]$. Confirmation of the absolute configuration of $\mathbf{1}$ was obtained through alkaline hydrolysis. As expected, the reaction produced (-)-5-hydroxy-(2E)-hexenoic acid, which corresponded to the triketide moiety of the same family of macrodiolides; confirmation of this was obtained from the ${ }^{1} \mathrm{H}$ NMR spectrum and its specific rotation $[6,10]$.

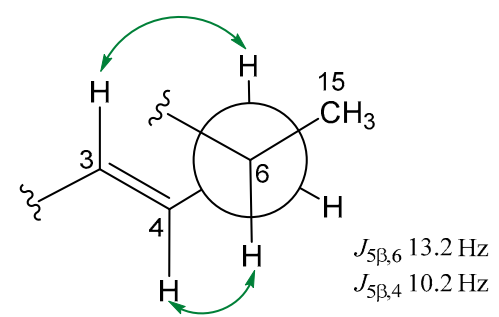

A

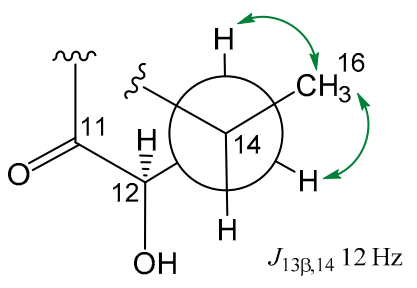

B

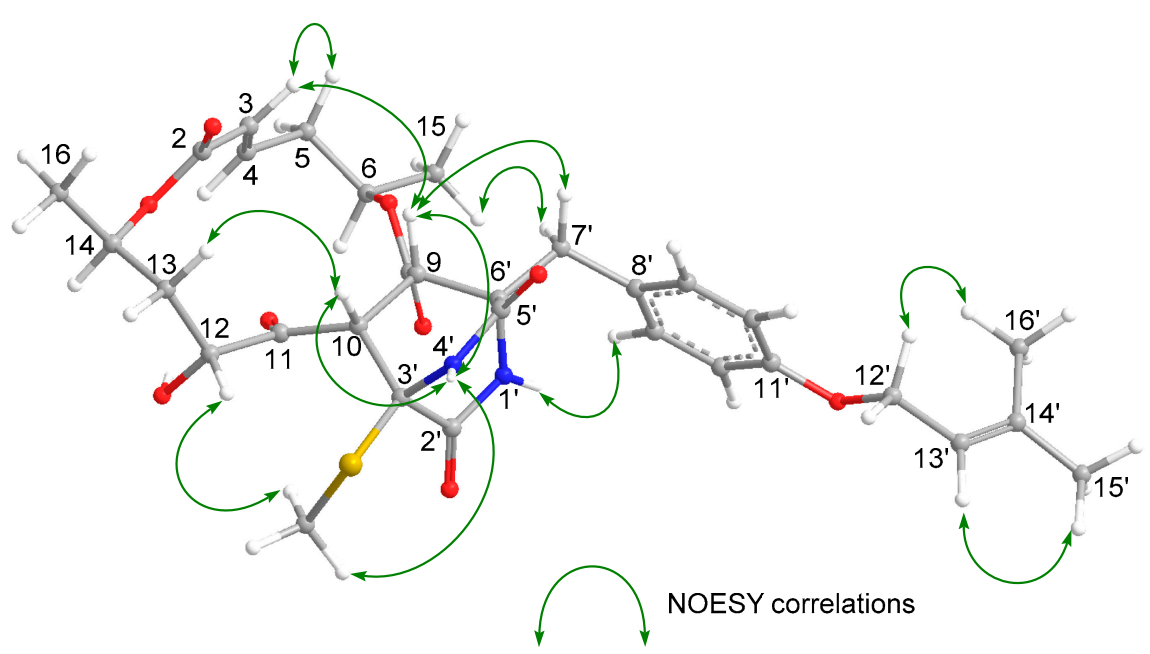

Figure 3. Key NOESY correlations for 1.

Previous biosynthetic studies showed that colletodiol (2) was produced from the epoxide derivative (I) induced from the cyclic triene (II), which was formed via cyclization between the $\mathrm{C}_{6}$ precursor (III) and the $\mathrm{C}_{8}$ precursor (IV) $[28,29]$. Additionally, oxygen-labeling experiments revealed that colletoketol was derived from 2 via the oxidative process [28]. Therefore, we hypothesized the biosynthetic pathway of 1 from colletoketol. Briefly, the 6- $\mathrm{SCH}_{3}$ group in the 3,6-bis(methylthio)-2,5-piperazinedione derivative (the thiosilvatin analogue) was eliminated as a result of the abstraction of an amide proton via 
enzymatic dehydrogenation. Subsequently, the $\pi$-electron at C-9 in the macrodiolide attacked C-6 in the thiosilvatin analogue as a nucleophile, forming a bond between C-9 and C- $6{ }^{\prime}$ in $\mathbf{1}$. Next, C-10 in the macrodiolide was attacked by $\mathrm{C}-3$ in the piperazinedione, which eliminated a proton to form the bond between C-10 and C-3' in 1 (Scheme 1). Since our hypothesis of the biosynthetic pathway suggests that stereoisomers of $\mathbf{1}$ at C-9, C-10, C-3', or C-6' exist, we will conduct further research to isolate and characterize the related metabolites from this fungus.<smiles>CC[C@H](C)C[Pb]C(=O)/C=C/C=C/C[C@H](C)O</smiles>

(IV)<smiles>C[C@H]1C/C=C\C(=O)O[C@@H](C)C/C=C\C=C/C(=O)O1</smiles>

(II)

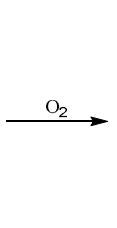

3,6-bis(methylthio)-2,5-piperazinedione

<smiles>C/C=C/C(=O)O[C@H](C)C/C=C\C(=O)O[C@H](C)C[C@@H](O)[C@@H](O)CO</smiles>

2
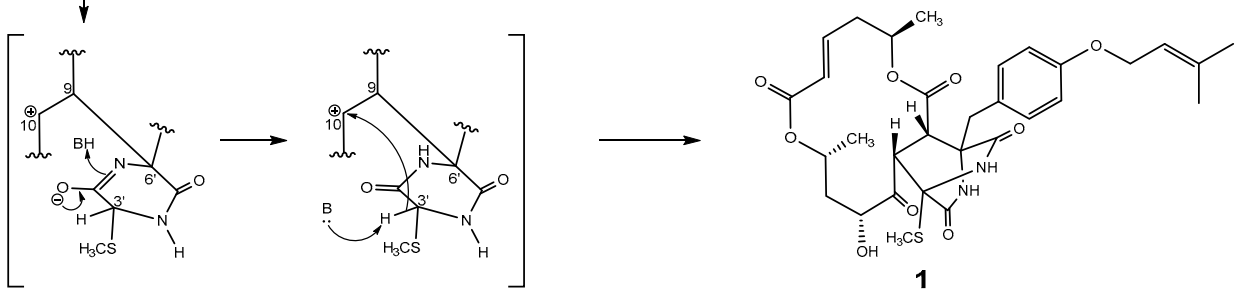

Scheme 1. Plausible biosynthetic pathway toward 1.

The cancer cell growth inhibitory properties of halosmysin A (1) and colletodiol (2) were examined using murine P388 leukemia, human HL-60 leukemia, and murine L1210 leukemia cell lines as a primary screen for antitumor activity (Table 2). According to the results, $\mathbf{1}$ exhibited a potency on par with that of 5-fluorouracil against the above-mentioned cell lines, whereas $\mathbf{2}$ did not inhibit cell growth at all. In a previous paper [25], the cytotoxicity of the thiosilvatin analogue was reported to be weak or inactive. Interestingly, the compound conjugated between the macrodiolide and the piperazinedione derivatives such as 1, significantly inhibited the growth of cancer cell lines. Since there are no reports on macrodiolide bound to other molecules, the study of the structure-activity relationship is yet to begin. In order to examine the structure-activity relationship and elucidate details about the compound's mode of action, we will conduct further studies on related fungal metabolites, including the stereoisomers of 1 .

Table 2. Cytotoxicity of metabolites $\mathbf{1}$ and $\mathbf{2}$ against cancer cell lines.

\begin{tabular}{cccc}
\hline \multirow{2}{*}{ Compounds } & Cell Line P388 & Cell Line HL-60 & Cell Line L1210 \\
\cline { 2 - 4 } & IC $_{\mathbf{5 0}}(\boldsymbol{\mu M})^{\mathbf{a}}$ & IC $^{\mathbf{5 0}}(\boldsymbol{\mu M})^{\mathbf{a}}$ & IC $_{\mathbf{5 0}}(\boldsymbol{\mu M})^{\mathbf{a}}$ \\
\hline $\mathbf{1}$ & $6.8 \pm 1.1$ & $2.2 \pm 3.1$ & $11.7 \pm 2.8$ \\
$\mathbf{2}$ & $>300$ & $>300$ & $>300$ \\
DMSO (control) & $>300$ & $>300$ & $>300$ \\
5-fluorouracil $^{\mathbf{b}}$ & $3.9 \pm 1.8$ & $0.2 \pm 2.5$ & $0.2 \pm 1.2$ \\
\hline
\end{tabular}

${ }^{\mathbf{a}}$ DMSO was used as the vehicle; ${ }^{\mathbf{b}}$ Positive control. 


\section{Materials and Methods}

\subsection{General Experimental Procedures}

The following procedures are the same as those in previous reports [5]. The NMR spectra were recorded on an Agilent-NMR-vnmrs (Agilent Technologies, Santa Clara, CA, USA) 600 with tetramethylsilane (TMS) as an internal reference. FABMS was recorded using a JEOL JMS-7000 mass spectrometer (JEOL, Tokyo, Japan). IR spectra were recorded on a JASCO FT/IR-680 Plus (Tokyo, Japan). Optical rotations were measured using a JASCO DIP-1000 digital polarimeter (Tokyo, Japan). Silica gel 60 (230-400 mesh, Nacalai Tesque, Inc., Kyoto, Japan) was used for column chromatography with medium pressure. ODS HPLC was run on a JASCO PU-1586 (Tokyo, Japan), equipped with a differential refractometer RI-1531 (Tokyo, Japan) and Cosmosil Packed Column 5C18-MSII (25 cm $\times 20 \mathrm{~mm}$ i.d., Nacalai Tesque, Inc., Kyoto, Japan). Analytical TLC was performed on precoated Merck aluminum sheets (DC-Alufolien Kieselgel 60 F254, 0.2 mm, Merck, Darmstadt, Germany) with the solvent system $\mathrm{CH}_{2} \mathrm{Cl}_{2}-\mathrm{MeOH}$ (19:1) (Nacalai Tesque, Inc., Kyoto, Japan), and compounds were viewed under a UV lamp (AS ONE Co., Ltd., Osaka, Japan) and sprayed with 10\% $\mathrm{H}_{2} \mathrm{SO}_{4}$ (Nacalai Tesque, Inc., Kyoto, Japan), followed by heating.

\subsection{Fungal Material}

The fungus Halosphaeriaceae sp. was isolated from the surface of the marine alga Sargassum thunbergii. Halosphaeriaceae sp. was collected at Osaka Bay, Japan in July 2017. The fungal strain was identified based on the result of its internal transcribed spacer (ITS) rDNA nucleotide sequence analysis by Techno Suruga Laboratory Co., Ltd. (Shizuoka, Japan). The alga Sargassum thunbergii was wiped with $\mathrm{EtOH}$ and a cutting applied to the surface of the nutrient agar layered in a Petri dish. Serial transfers of one of the resulting colonies provided a pure strain of Halosphaeriaceae sp.

\subsection{Culturing and Isolation of Metabolites}

The fungus was cultured at $27^{\circ} \mathrm{C}$ for four weeks in a medium $(80 \mathrm{~L})$ containing $1 \%$ glucose, $1 \%$ malt extract, and $0.05 \%$ peptone in artificial seawater adjusted to $\mathrm{pH} 7.5$. Then, the culture filtrate was extracted thrice with AcOEt. The combined extracts were evaporated in vacuo to afford a mixture of crude metabolites $(3.0 \mathrm{~g})$. The EtOAc extract was chromatographed on a silica gel column, with a $\mathrm{CH}_{2} \mathrm{Cl}_{2} / \mathrm{MeOH}$ gradient as the eluent to afford Fr. 1 ( $2 \% \mathrm{MeOH}$ in $\mathrm{CH}_{2} \mathrm{Cl}_{2}$ eluate, $121.2 \mathrm{mg}$ ). Fr. 1 was purified by ODS HPLC, using $\mathrm{MeOH} / \mathrm{H}_{2} \mathrm{O}$ (70:30) as the eluent to afford 1 (3.2 mg) and 2 (20.7 mg).

Halosmysin A (1): pale yellow oil; $[\alpha]_{22}^{D}+105.6$ (c 0.048, $\mathrm{CHCl}_{3}$ ); IR (neat) $v_{\max } / \mathrm{cm}^{-1}: 3193,2930,2862$, $1722,1706,1657,1612,1510$. HRFABMS $m / z 615.2380[\mathrm{M}+\mathrm{H}]^{+}$(calcd for $\mathrm{C}_{31} \mathrm{H}_{39} \mathrm{~N}_{2} \mathrm{O}_{9} \mathrm{~S}: 615.2376$ ); NMR data, see Table 1 and Table S1.

\subsection{Alkaline Hydrolysis of $\mathbf{1}$}

First, $1(2.8 \mathrm{mg})$ and $0.1 \mathrm{~N} \mathrm{NaOH}$ aq. (1 mL) were stirred at room temperature for $15 \mathrm{~h}$, then acidified with $1 \mathrm{~N} \mathrm{HCl}$ and extracted with AcOEt. The organic layer was evaporated in vacuo, and the residue was purified by ODS HPLC, using $\mathrm{MeOH} / \mathrm{H}_{2} \mathrm{O}(0.1 \% \mathrm{AcOH})(30: 70)$ as the eluent to (-)-5-hydroxy-(2E)-hexenoic acid (0.9 mg) (r.t. $28.5 \mathrm{~min})$.

(-)-5-hydroxy-(2E)-hexenoic acid: clear oil; $[\alpha]_{22}^{D}-14.3$ (c 0.09, EtOH); ${ }^{1} \mathrm{H}$ NMR $\left(600 \mathrm{MHz}, \mathrm{MeOH}-\mathrm{d}_{4}\right) \delta$ ppm: $1.16(3 \mathrm{H}, \mathrm{d}, \mathrm{J}=6.0 \mathrm{~Hz}), 2.31(2 \mathrm{H}, \mathrm{dd}, \mathrm{J}=6.0,6.0 \mathrm{~Hz}), 3.85(1 \mathrm{H}, \mathrm{sext}, \mathrm{J}=6.0 \mathrm{~Hz}), 5.92(1 \mathrm{H}, \mathrm{br} \mathrm{s})$, $6.88(1 \mathrm{H}, \mathrm{m})$.

\subsection{Assay for Cytotoxicity}

The cytotoxic activities of $\mathbf{1}$ and $\mathbf{2}$ were examined by the same procedure to date [5]-the 3-(4,5-dimethyl-2-thiazolyl)-2,5-diphenyl- 2H-tetrazolium bromide (MTT) method. The P388, HL-60, and L1210 cells were cultured in an RPMI 1640 Medium (10\% fetal calf serum) at $37{ }^{\circ} \mathrm{C}$ in $5 \% \mathrm{CO}_{2}$. 
The test materials were dissolved in dimethyl sulfoxide (DMSO) to give a concentration of $10 \mathrm{mM}$, and the solution was diluted with the Essential Medium to yield concentrations of 200, 20, and $2 \mathrm{M}$, respectively. Each solution was combined with each cell suspension $\left(1 \times 10^{-5}\right.$ cells $\left./ \mathrm{mL}\right)$ in the medium, respectively. After incubating at $37^{\circ} \mathrm{C}$ for $72 \mathrm{~h}$ in $5 \% \mathrm{CO}_{2}$, the grown cells were labeled with $5 \mathrm{mg} / \mathrm{mL}$ MTT in phosphate-buffered saline (PBS), and the absorbance of formazan dissolved in $20 \%$ sodium dodecyl sulfate (SDS) in $0.1 \mathrm{~N} \mathrm{HCl}$, was measured at $540 \mathrm{~nm}$ with a microplate reader (MTP-310, CORONA electric). Each absorbance value was expressed as a percentage relative to that of the control cell suspension, which was prepared without the test substance, using the same procedure described above. All of the assays were performed three times, semilogarithmic plots were constructed from the averaged data, and the effective dose of the substance required to inhibit cell growth by $50 \%\left(\mathrm{IC}_{50}\right)$ was determined.

\subsection{The Origin of the Cell Lines}

The P388 cell line was obtained from Dr. Numata, the HL-60 cell line from Dr. Kawai (death), and the L1210 cell line from Dr. Endo.

\section{Conclusions}

In conclusion, we have isolated a new macrodiolide, halosmysin A (1), as a structurally unprecedented secondary metabolite from the fungus Halosphaeriaceae sp., separated from the marine alga Sargassum thunbergii. In addition, we have proposed a plausible biosynthetic pathway toward 1 from the known macrodiolide, colletodiol (2), which was also isolated from the same fungal strain. This compound exhibited stronger cytotoxicity than $\mathbf{2}$ and the piperazinedione derivative, which were constituent molecules of $\mathbf{1}$. In the near future, we will publish further research on the new, fused macrodiolides or the stereoisomer of $\mathbf{1}$, to elucidate both the structure-activity relationship and the mechanism of activity.

Supplementary Materials: The following are available online at http://www.mdpi.com/1660-3397/18/6/320/s1, Table S1: Spectral data including 2D NMR data for 1, Figure S1: 14-membered macrodiolides associated to halosmysin A, Figure S2: ${ }^{1} \mathrm{H}$ NMR spectrum of $\mathbf{1}$ in $\mathrm{CDCl}_{3}$, Figure S3: ${ }^{13} \mathrm{C}$ NMR spectrum of $\mathbf{1}$ in $\mathrm{CDCl}_{3}$, Figure S4: ${ }^{1} \mathrm{H}^{-1} \mathrm{H}$ COSY of 1, Figure S5: NOESY of 1, Figure S6: HMQC of 1, Figure S7: HMBC of 1, Figure S8: FABMS of 1.

Author Contributions: Conceived and designed the experiments: T.Y., T.K. and T.H.; Performed the experiments: H.K. and M.K.; Analyzed the data: T.Y.; and Wrote the paper: T.Y. All authors have read and agreed to the published version of the manuscript.

Funding: This research received no external funding.

Acknowledgments: We thank Endo (Kanazawa University) for the supply of cancer cells. We are grateful to M. Fujitake and K. Minoura of the same university for MS and NMR measurements, respectively.

Conflicts of Interest: The authors declare no conflict of interest.

\section{References}

1. Nicoletti, R.; Vinale, F. Bioactive Compounds from Marine-Derived Aspergillus, Penicillium, Talaromyces and Trichoderma Species. Mar. Drugs 2018, 16, 408. [CrossRef]

2. Imhoff, J.F. Natural Products from Marine Fungi-Still an Underrepresented Resource. Mar. Drugs 2016, 14, 19. [CrossRef]

3. Blunt, J.W.; Copp, B.R.; Keyzers, R.A.; Munro, M.H.G.; Prinsep, M.R. Marine natural products. Nat. Prod. Rep. 2017, 34, 235-294. [CrossRef] [PubMed]

4. Blunt, J.W.; Carroll, A.R.; Copp, B.R.; Davis, R.A.; Keyzers, R.A.; Prinsep, M.R. Marine natural 369 products. Nat. Prod. Rep. 2018, 35, 8-53. [CrossRef] [PubMed]

5. Yamada, T.; Kitada, H.; Kajimoto, T.; Numata, A.; Tanaka, R. The relationship between the CD Cotton effect and the absolute configuration of FD-838 and its seven stereoisomers. J. Org. Chem. 2010, 75, 4146-4153. [CrossRef] [PubMed] 
6. MacMillan, J.; Simpson, T.J. Fungal Products. Part V. The absolute stereochemistry of colletodiol and the structures of related metabolites of Colletotrichum capsici. J. Chem. Soc. Perkin Trans. 1 1973, 1487-1493. [CrossRef]

7. Ronald, R.C.; Gurusiddaiah, S. Grahamimycin $\mathrm{A}_{1}$ : A novel dilactone antibiotic from Cytospora. Tetrahedron Lett. 1980, 21, 681-684. [CrossRef]

8. Gurusiddaiah, S.; Ronald, R.C. Grahamimycins: Antibiotics from Cytospora sp. Ehrenb. W.F.P.L. 13A. Antimicrob. Agents Chemother. 1981, 19, 681-684. [CrossRef]

9. Hanson, K.; O'neill, J.A.; Simpson, T.J.; Willis, C.L. Bartanol and bartallol, novel macrodiolides from Cytospora sp. ATCC 20502. J. Chem. Soc. Perkin Trans. 1 1994, 2493-2497. [CrossRef]

10. Höller, U.; König, G.M.; Wright, A.D. A new tyrosine kinase inhibitor from a marine isolate of Ulocladium botrytis and new metabolites from the marine fungi Asteromyces cruciatus and Varicosporina ramulosa. Eur. J. Org. Chem. 1999, 2949-2955. [CrossRef]

11. Grabley, S.; Hammann, P.; Thiericke, R.; Wink, J. Secondary metabolites by Chemical screening. 21 Clonostachydiol, a novel anthelmintic macrolide from the fungus Clonostachys cylindrospora (strain FH-A 6607). J. Antibiot. 1992, 46, 343-345. [CrossRef] [PubMed]

12. Lang, G.; Mitova, M.I.; Ellis, G.; van der Sar, S.; Phipps, R.K.; Blunt, J.W.; Cummings, N.J.; Cole, A.L.J.; Munro, M.H.G. Bioactivity profiling using HPLC/microtiter-plate analysis: Application to a New Zealand marine alga-derived fungus, Gliocladium sp. J. Nat. Prod. 2006, 69, 1007-1010. [CrossRef] [PubMed]

13. Ojima, K.; Yangchum, A.; Laksanacharoen, P.; Tasanathai, K.; Tanakitpipattana, D.; Tokuyama, H.; Isaka, M. Cordybislactone, a stereoisomer of the 14-membered bislactoneclonostachydiol, from the hopper pathogenic fungus Cordyceps sp. BCC 49294: Revision of the absolute configuration of clonostachydiol. J. Antibiot. 2018, 71, 351-358. [CrossRef] [PubMed]

14. Isaka, M.; Yangchum, A.; Auncharoen, P.; Srichomthong, K.; Srikitikulchai, P. Ring B aromatic norpimarane glucoside from a Xylaria sp. J. Nat. Prod. 2011, 74, 300-302. [CrossRef]

15. Han, J.; Su, Y.; Xu, Y.; Huo, X.; She, X. Asymmetric total synthesis and revision of the absolute configuration of 4-Keto-clonostachydiol. J. Org. Chem. 2009, 74, 3930-3932. [CrossRef] [PubMed]

16. Berg, A.; Notni, J.; Dorfelt, H.; Grafe, U. Acremonol and acremodiol, new fungal bislactones. J. Antibiot. 2002, 55, 660-662. [CrossRef] [PubMed]

17. Wang, T.T.; Wei, Y.J.; Ge, H.M.; Tan, R.X. Acaulide, an osteogenic macrodiolide from Acaulium sp. H-JQSF, an isopod-associated fungus. Org. Lett. 2018, 20, 1007-1010. [CrossRef]

18. Amstutz, R.; Hungerbühler, E.; Seebach, D. Revidierte struktur des makrodiolids colletodiol. Helv. Chim. Acta 1981, 6, 1796-1799. [CrossRef]

19. Khomane, N.B.; Kumar, R.N.; Mali, P.R.; Shirsat, P.K.; Meshram, H.M. Formal synthesis of 14-membered unsymmetrical bis-macrolactone, (-)-colletodiol. Tetrahedron Lett. 2017, 58, 4687-4690. [CrossRef]

20. Rao, A.V.R.; Murthy, V.S.; Sharma, G.V.M. Studies directed towards the synthesis of clonostachydiol-Part I. Tetrahedron Lett. 1995, 36, 139-142. [CrossRef]

21. Rao, A.V.R.; Murthy, V.S.; Sharma, G.V.M. The first synthesis and determination of absolute stereochemistry of clonostachydiol-Part II. Tetrahedron Lett. 1995, 36, 143-146. [CrossRef]

22. Yadav, J.S.; Swamy, T.; Subba Reddy, B.V. A stereoselective approach for the total synthesis of clonostachydiol. Synlett 2008, 2773-2776. [CrossRef]

23. Ramulu, U.; Ramesh, D.; Rajaram, S.; Reddy, S.P.; Venkatesham, K.; Venkateswarlu, Y. Stereoselective total synthesis of clonostachydiol. Tetrahedron Asymmetry 2012, 23, 117-123. [CrossRef]

24. Chu, M.; Mierzwa, R.; Truumees, I.; Gentile, F.; Patel, M.; Gullo, V.; Chan, T.-M.; Puar, M.S. Two novel diketopiperazines isolated from the fungus Tolypocladium sp. Tetrahedron Lett. 1993, 34, 7537-7540. [CrossRef]

25. Usami, Y.; Aoki, S.; Hara, T.; Numata, A. New dioxopiperazine metabolites from a Fusarium species separated from a marine alga. J. Antibiot. 2002, 55, 655-659. [CrossRef] [PubMed]

26. Guimaraes, D.O.; Borges, W.S.; Vieira, N.J.; de Oliveira, L.F.; da Silva, C.H.T.P.; Lopes, N.P.; Dias, L.G.; Duran-Patron, R.; ColladoI., G.; Pupo, M.T. Diketopiperazines produced by endophytic fungi found in association with two Asteraceae species. Phytochemisry 2010, 71, 1423-1429. [CrossRef] [PubMed]

27. Salvatore, M.M.; Nicoletti, R.; DellaGreca, M.; Andolfi, A. Occurrence and properties of thiosilvatins. Mar. Drugs 2019, 17, 664. [CrossRef] [PubMed] 
28. Simpson, T.J.; Stevenson, G.I. Studies of polyketide chain-assembly processes: Origins of the hydrogen and oxygen atoms in colletodiol. J. Chem. Soc. Chem. Commun. 1985, 1822-1824. [CrossRef]

29. O'neill, J.A.; Simpson, T.J.; Willis, C.L. Biosynthesis of colletodiol and related polyketide macrodiolides in Cytospora sp. ATCC 20502: Synthesis and metabolism of advanced intermediates. J. Chem. Soc. Chem. Commun. 1993, 738-740. [CrossRef]

(C) 2020 by the authors. Licensee MDPI, Basel, Switzerland. This article is an open access article distributed under the terms and conditions of the Creative Commons Attribution (CC BY) license (http://creativecommons.org/licenses/by/4.0/). 